\title{
A voz do autor: a metaficção na criação de personagens em "Diário para um conto", de Cortázar
}

\author{
Author's voice: metafiction on character creation in \\ "Diário para um conto", by Cortázar
}

\author{
LUCIANA PASTORINI URBIM* \\ Universidade Federal de Pelotas, Pelotas, RS, Brasil
}

\begin{abstract}
Resumo: Este artigo apresenta uma análise da narrativa breve "Diário para um conto", de Júlio Cortázar, retirado do livro Fora de Hora (1982), acerca dos mecanismos utilizados pelo escritor na criação de um conto, em especial de uma personagem, Anabel, em torno da qual orbita a história a ser contada. Com a finalidade de expor a problemática vivenciada pelo escritor na tarefa de escritura e de dar vida a um ser ficcional, Cortázar se utiliza de recursos metaficcionais que possibilitam espelhar a experiência criativa de um escritor ao tentar construir uma narrativa e seus elementos, evidenciando, sobretudo os conflitos em que ele se vê diante da criação da personagem, bem como seus limites entre realidade e ficção.
\end{abstract}

Palavras-chave: conto; escrita; criação de personagem; Cortázar; metaficção.

\begin{abstract}
This paper presents an analysis of "Diário para um conto" by Julio Cortázar, taken from the book Fora de hora (1982), about the mechanisms used by the writer in the creation of a short story, in particular, of a character, Anabel, around which the story is being told. With the goal of exposing the difficulties lived by the writer in the task to create and to give life to a fictional character, Cortázar uses metafictional resources that make it possible to mirror the creative experience of a writer attempting to build a narrative and its elements, especially the conflicts in which he finds himself before the creation of the character, as well as their limits between reality and fiction.
\end{abstract}

Keywords: short story; writing; character creation; Cortázar; metafiction. * Mestre em História da Literatura (FURG). Jornalista, revisora e especialista em Produção Textual (UFPel). Professora e
escritora, ex-aluna da Oficina de Criação Literária do professor Assis Brasil (PUCRS). <lurbim@gmail.com>. 


\section{Introdução}

"Larvatus prodeo: avanço mostrando minha máscara com o dedo." (ROLAND BARTHES)

O escritor argentino Julio Cortázar (1914-1984) dedicou sua vida a um complexo projeto literário que, ao longo dos anos, resultou em mais de 40 publicações, entre contos, novelas, romances, poesias e ensaios. Com um vasto reconhecimento, sobretudo como contista, Cortázar e sua obra se destacam por inúmeras razões. Além do cuidado formal que sempre o caracterizou, e da temática fantástica que marcou suas criações, o autor também se sobressai devido ao fato de ter produzido um amplo material de crítica literária, teorizando, inclusive, sobre suas próprias obras e seu processo de criação.

Sendo assim, é possível encontrar, em muitas de suas obras, temas referentes ao próprio ofício da escrita ou da criação literária, como vemos em "Diário para um conto", em que o autor faz da criação de uma personagem o tema que dispara e permeia toda sua narrativa.

O conto faz parte do livro Fora de Hora (1985), conjunto de oito narrativas curtas publicadas originalmente em 1982, com o título original de Deshoras, sendo esta uma de suas últimas obras publicadas ainda em vida.

O título, "Diário para um conto", já antecipa tanto o conteúdo temático da narrativa quanto sua forma, feita à semelhança de um diário. Os registros contidos têm a duração de cerca de um mês (de 02 a 28 de fevereiro de 1982), acompanhando o período no qual se desenvolve o processo de escrita de um conto, ou melhor, revelando os apontamentos dos bastidores de sua criação na tentativa de escrevê-lo, a partir das memórias do narrador-escritor.

Escrito em primeira pessoa, e com forte teor autobiográfico, o personagem narrador aparenta espelhar a figura do próprio Cortázar, que utiliza algumas de suas memórias e informações pessoais (marca de cigarros preferida, modelo de sua máquina de escrever, menção a um de seus autores preferidos, etc.) para auxiliar na construção do escritor que narra sobre a dificuldade em escrever sobre determinada figura feminina de seu passado, Anabel.

Às vezes, vai me invadindo uma espécie de comichão de conto, esse sigiloso e crescente deslocamento que me aproxima pouco a pouco e resmungando desta Olympia Traveller de Luxo (de luxo a pobre não tem nada, mas por outro lado tem travelliado pelos sete profundos mares azuis aguentando tudo quanto é golpe direto e indireto que pode receber uma portátil metida em uma mala entre calças, garrafas de rum e livros), é assim às vezes, quando cai a noite e ponho uma folha em branco no rolo e acendendo um Gitane me chamo de estúpido (para que um conto, afinal, por que não abrir um livro de outro contista, ou escutar um dos meus discos?), mas às vezes, quando já não posso fazer outra coisa a não ser começar um conto como quereria começar este, é quando eu gostaria exatamente de ser Adolfo Bioy Casares (CORTÁZAR, 1985, p. 145).

Logo, desde o primeiro parágrafo da narrativa, é apresentado ao leitor não só o conflito do escritor diante da tarefa de criar a personagem e contar sua história, como também a escolha de fazer uso de um personagem-narrador, tanto para executar essa tarefa quanto para discuti-la com o leitor. 


\section{Anabel e seus reflexos: realidade $\times$ ficção}

No decorrer da narrativa, o narrador vai apresentando ao leitor, através das confissões em seu diário, a dificuldade tamanha em criar essa representação feminina, inspirada em alguém que conhecera. Recorre ao tratamento dado por outro escritor, Bioy Casares, para refletir acerca da árdua tarefa de dar vida a alguém no papel:

Naturalmente em nenhuma das três ocasiões falamos de Anabel, mas não é por isso que agora eu desejaria ser Bioy, mas porque me agradaria tanto poder escrever sobre Anabel como ele o teria feito se a tivesse conhecido e tivesse escrito um conto sobre ela. Nesse caso Bioy teria falado de Anabel como eu serei incapaz de fazê-lo, mostrando-a próxima e profundamente e ao mesmo tempo guardando essa distância, esse desprendimento que decide pôr (não posso pensar que não seja uma decisão) entre alguns de seus personagens e o narrador.

Com esse trecho, Cortázar determina o quanto, para ele, é inconcebível tal distanciamento. Impossibilidade essa que assume o tom que conduz a narrativa, do início até seu fim, bem como revela a luta do autor com a linguagem e suas limitações na realização do trabalho criativo de trazer à vida uma personagem.

Para mim vai ser impossível, e não só porque tenha conhecido Anabel, visto que quando crio personagens também não consigo me distanciar deles, se bem que às vezes me pareça tão necessário como ao pintor que se afasta do cavalete para abranger melhor a totalidade de sua pintura e saber onde deve dar as pinceladas definidoras. Não me será possível, pois sinto que Anabel vai me invadir já de início como quando a conheci em Buenos Aires no final dos anos quarenta, e embora ela fosse incapaz de imaginar este conto - se vive, se ainda anda por aí, velha como eu -, fará também o possível para me impedir que escreva sobre isso como eu teria gostado, isto é, um pouco como Bioy teria sabido escrevê-lo se tivesse conhecido Anabel.

As questões colocadas pelo narradorautor, como sua dificuldade em separar realidade de ficção e o medo de ser invadido pela personagem, perdendo o controle sobre a narrativa, remetem a algumas das dificuldades centrais vividas por todo escritor na criação de seus personagens, ilustrando tais dilemas que fazem parte da discussão da criação literária.

No conto em questão, Cortázar apresenta os registros feitos pelo narrador, em forma de um diário, em relação a sua tentativa de escrever sobre Anabel, personagem com quem ele se envolveu e vivenciou uma estranha experiência acerca de um assassinato. Assim, dia após dia, o narrador-autor expõe a dificuldade em rememorar os fatos deste período de seu passado e, logo, a impossibilidade de recriar Anabel. No entanto, através de tais relatos, o personagem tenta reconstruir os eventos relacionados à presença de Anabel em sua vida e no que ela acabou, indiretamente, envolvendo-o: o assassinato de uma prostituta.

Destaca-se então a reflexão complexa acerca da criação narrativa, referente a um espelhamento, uma vez que Cortázar se projeta no personagem narradorautor, mergulhando assim em sua ficção, transformando-se em ficção; espelhandose em um ente ficcional e contagiando sua narrativa de realidade, bem como banhando a realidade de ficção. 
Nesse sentido, a forma metaficcional e sua função, ou seja, a proposta estética da obra revelada pelo uso da metaficção acaba por espelhar não apenas o autor, como também o leitor ao fazê-lo enxergarse, por meio do exercício reflexivo do escritor-narrador, em sua incompletude.

Ao estabelecer esta conexão, cria-se o elo necessário à totalidade da escrita, desenhando este triângulo que aproxima autor - obra - leitor, realizando o propósito do texto enfim, por meio da narrativa com a qual o autor luta, na tentativa de trazê-la ao mundo, de contá-la da melhor forma: a história de Anabel. Ao mesmo tempo em que procura também narrar sua experiência de escritura, demonstrado as estratégias narrativas que ele opta por utilizar, no intuito de contar a história da intrigante personagem.

Para Cortázar, a linha entre ficção e realidade consistia numa corda bamba, na qual ele se movia à vontade, brincando com os limites. Mesmo entendendo a ficção aqui como uma espécie de "fingimento" do real, contraposto à realidade em si, é impossível não vê-los de forma interligada, assim como propõe Theodor Fontane ao dizer que um romance "deve contar-nos uma história na qual acreditamos", em que "um mundo de ficção deve parecer por alguns instantes como um mundo da realidade". (FONTANE apud HAMBURGER, 2013, p.41). Portanto, criar uma narrativa que seja "como um mundo da realidade" significa dizer, de forma paradoxal, desenvolver uma ficção que se assemelhe à realidade.

Se perguntarmos, porém, por que é aqui e somente aqui que se produz ilusão, a 'estrutura como' da realidade, a resposta é: porque aqui se cria a ilusão da vida. E a ilusão da vida é criada pela Arte somente por um 'eu' vivo, que pensa, sente, fala. As figuras de um romance ou drama são personagens fictícios porque são constituídos como 'eus' fictícios (...) Entre todos materiais das artes, porém, é somente a linguagem que pode produzir a ilusão da vida, isto é, criar personagens vivos, sensíveis, pensativos, que falam e também se calam (HAMBURGER, 2013, p. 42).

Esta "ilusão da vida" pretendida pela Arte busca representar a realidade em seu processo de criação, fazendo da ficção algo crível, ainda que inventado. O processo criativo surge então como uma intuição da realidade, uma maneira de relacionarse com o mundo, com o entorno, com as experiências, ou melhor, com a vida em si, conforme expõe o filósofo alemão Hans Vaihinger ao afirmar que "as ficções são formações psíquicas", pois "a mente tece esses meios auxiliares graças à criatividade da alma; movida pela necessidade e estimulada pelo mundo exterior" (VAIHINGER apud BERNARDO, 2010, p. 19).

Confrontado com as ameaças de fora (do mundo) e de dentro (de si mesmo), o ser humano reage fabulando: atribui sentido ao que se lhe apresenta sem sentido. Essa reação fabuladora é que constrói a civilização e suas instituições. A ficção é menos uma diversão do que um escudo contra as ameaças externas e internas, obrigando-nos a narrar uma luta interminável: o drama que nos constitui (BERNARDO, 2010, p. 20).

Para o crítico David Lodge, tais mecanismos "lisonjeiam o leitor ao tratá-lo como um intelecto elevado e sofisticado o bastante para não se chocar com a confissão de que uma obra de ficção é uma construção verbal, e não um fragmento da vida" (LODGE, 2010, p. 214). Neste sentido, tal ideia se oporia a criação de uma "ilusão da vida", justificada pela ficção. Ao 
contrário, buscaria desconstruir tal ilusão, revelando-a ao leitor.

Em $A$ arte da ficção, John Gardner destaca que, com o recurso de metaficção, "o escritor perturba o leitor" quando "permite ou faz com que o leitor pare de pensar na história (de ver a história) para pensar em outra coisa" (GARDNER, 1997, p. 52). Esta "outra coisa" pode ser o procedimento de escrita em si, ou algo do tipo, que faça com se interrompa o "sonho ficcional" do leitor durante a leitura, chamando sua atenção para o método, tornando tais interrupções tão importantes quanto o sonho.

Eles [os escritores] permitem ao leitor uma experiência que terá seu ponto de partida no convívio habitual com a ficção. O possível efeito que sua obra venha a ter dependerá dessa violação consciente do habitual efeito ficcional (GARDNER, 1997, p. 52).

Com isso, o crítico destaca que o efeito do recurso será voltado para o leitor já acostumado com a narrativa tradicional, que perceberá a ruptura ocorrida, identificando-a e entrando no jogo do autor. É como se o autor buscasse chamar a atenção do leitor para o procedimento da escritura da obra que este está lendo, durante seu desenvolvimento, convidando-o a participar do seu ato de criação. Para Gardner, toda metaficção é uma forma de desconstrução, isto é, uma "prática de desmontar a linguagem" para revelar seu "mecanismo interior, que passa geralmente despercebido" (GARDNER, 1997, p. 123).

Esta forma de ficção não convencional, buscada com o uso da metaficção, nos permite pensá-la como recurso crítico, e ao mesmo tempo estilístico, escolhido previamente pelo autor com a finalidade específica de representar a realidade do ofício da escrita, por meio da ficção. Assim, o escritor pode utilizar um personagem-autor como espelhamento de si, ficcionalizando sua prática e criando uma ponte entre diferentes ficções, como afirma Bernardo:

No entanto, se a realidade de que trata o conto é a realidade deste personagem, ora, ela também é fictícia. Logo, se há comunicação, ela se dá entre diferentes níveis de ficção. (...) A ponte entre esses níveis diferentes de ficção tem o nome de 'metaficção'. É uma ponte interna, e nela se pensa a ficção dentro da ficção (BERNARDO, 2010, p. 37).

Esta "ponte" criada entre os diferentes níveis de ficção dentro de uma obra é a forma estabelecida pelo autor para evidenciar os mecanismos que movem a criação do texto, chamando a atenção do leitor, convidando-o a percorrê-la. Nesta direção, podemos dizer que "a metaficção é uma ficção que não esconde que o é, mantendo o leitor consciente de estar lendo um relato ficcional" (BERNARDO, 2010, p. 42). Tal caráter da metaficção nos leva a pensar o quanto ela também serve como forma de reflexão sobre o fazer literário, pondo em dúvida os tradicionais papéis autor/leitor, bem como os elementos narrativos, gêneros textuais, etc., produzindo a desconstrução da literatura enquanto tal.

A metaficção desconfia da realidade, logo desconfia do realismo. A metaficção desconfia do autor, logo desconfia também do leitor. A metaficção desconfia de si mesma, logo desconfia de qualquer presunção de identidade. Sua característica principal é a autoconsciência, mas uma autoconsciência irônica e, de certo modo, trágica. Ao se voltar para si mesma, ela se põe à beira de um abismo (BERNARDO, 2010, p. 52). 
Isso simbolizaria uma jornada urobórica da narrativa seguindo atrás de si mesma, de seu princípio, circularmente, buscando compreender-se enquanto prática de escrita, criação e forma. Se a literatura em si já é um desvio da linguagem comum, de acordo com Eagleton (2006), então podemos pensar que a metaficção representaria um segundo desvio, uma duplicação deste.

Todas estas são maneiras de chamar a atenção do leitor, quebrando o "pacto ficcional", ou seja, interrompendo o leitor de seu sonho induzido pela narrativa, conforme exposto por Gardner anteriormente. Desta forma, chama-se a atenção do leitor para o fazer literário, para além do próprio texto que ele tem em mãos. Mais do que ficção, mais do que espelho, o autor cria uma passagem secreta. Desdobra-se, assim, um labirinto dentro da página que surge convidando o leitor a percorrer suas entranhas, adentrar uma zona subterrânea, antes só possibilitada ao criador.

\section{Espelhamentos entre autor, narrador e personagem}

A Anabel de Cortázar, como o próprio conto revela, é baseada em Annabel Lee, personagem do poema homônimo de Edgar Allan Poe sobre um amor perdido do passado, relembrado pelo eu lírico. A partir dessa analogia é que Cortázar inicia a construção de sua Anabel, traçando uma linha comparativa de semelhanças e diferenças entre as duas mulheres.

- Bem - eu teria dito -, comecemos porque era uma república e não um reino nessa época, mas além disso Anabel escrevia seu nome com um ene só, sem contar que many and many years ago tinha deixado de ser uma maiden, não por culpa de Edgar Allan
Poe, mas de um viajante comercial de Trenque Lauquen que a deflorou aos treze anos. Isso sem falar que além disso se chamava Flores e não Lee, e que teria dito descabaçar em vez da outra palavra que ignorava totalmente.

Evocar elementos poéticos para auxiliar na criação de sua personagem indica o quanto Anabel não diz mais respeito a alguém de carne e osso, mas sim a um ser ficcional, inventado. Ainda que possa trazer resquícios de uma pessoa do mundo real, isso não mais importa, pois o que realmente Ihe dará vida são os elementos utilizados para enriquecê-la no próprio texto.

Com isso, Cortázar desvia a atenção do leitor, por meio do recurso metaficcional, também sugerindo deslocar o próprio escritor, tirando-o de seu lugar-comum. E é dessa forma, falando sobre deslocamentos de realidades, que o autor inicia seu conto ao falar sobre o "sigiloso e crescente deslocamento" que o leva a sair de sua rotina e buscar pela máquina de escrever, para atender a um chamado criativo, denominado por ele de "comichão de conto" (CORTÁZAR, 1985, p. 145).

Com esta abertura, o autor "brinca" com os limites do ficcional, pois enquanto fala através do narrador, antecipa ao leitor que é um escritor que está "fazendo ficção" ao contar seu processo de construção, iniciado com um "chamado" do conto que, pouco a pouco, vai retirando-o da realidade e o fazendo embarcar em um mundo imaginário, alhures.

A referência a outro contista argentino, Adolfo Bioy Casares, contemporâneo de Cortázar, e como ele também mestre do fantástico, auxilia o leitor a vislumbrar as diferentes opções de narração e de tratamento de tema que podem ser dados ao conto que ele pretende narrar, expondo 
o quanto a narrativa depende dessa escolha para ir adiante, para se construir.

Dessa forma, como um alquimista, antes de preparar seu experimento, Cortázar apresenta os possíveis elementos a serem utilizados por ele, evidenciando ao leitor suas escolhas na condução do desenvolvimento da história. Neste movimento, o autor aponta para sua máscara:

Toda mensagem literária deve ser transubstanciada pela subjetividade que a modela, embebendo-a de mesmidade pessoal - "não há mensagem, há mensageiros e essa é a mensagem, assim como o amor é quem ama", irá dizer no capítulo 79 de $O$ jogo da amarelinha -, embora a escrita se mostre afinal como um recurso para atingir o que está aquém ou além da língua, a realidade que as palavras mascaram (YURKIEVICH, 1998, p. 14).

Sendo assim, desde a primeira linha o autor expõe sua condição de narrador, apontando para seu eu fictício, isto é, sua máscara narrativa que, de antemão, avisa ao leitor: isto não é real. Com isso Cortázar chama a atenção para o mensageiro, indicando que é em torno dele que orbitarão os mecanismos de funcionamento da ficção.

Partindo da imagem de Escher, enquanto paradoxo metaficcional, podemos vislumbrar o conto de Cortázar sob a égide do mesmo desenho, ainda que traçado com palavras, a formar a mão do escritor a escrever, a contar sobre o contista que escreve um conto. Um conto sobre um terceiro personagem, Anabel. Entretanto, como bem alerta o autor, o texto que se acusa ser sobre Anabel, não é sobre ela, e sim sobre a dificuldade de um autor em criar e escrever sobre seu personagem.
Ao evidenciar ao leitor, desde o princípio, que o que ele está lendo não se trata da realidade, mas sim uma criação, Cortázar apresenta sua "verdade estética", conforme falava Machado de Assis: "aquela que não esconde do seu leitor que faz ficção, inventando uma realidade de papel a partir de suas observações parciais da realidade 'real'" (ASSIS apud BERNARDO, 2010, p. 146).

Desse modo, o autor parte da realidade para recriá-la, duplicá-la, não visando apenas apropriar-se dela e amplificá-la, mas sim transcendê-la, confundindo-a com a ficção. Para Bernardo, esta seria a grande dúvida existencial de que fala a metaficção: "a realidade é real ou ilusória?" (2010, p. 162).

Tal ocorrência de metaficção, logo de partida, deixa claro de onde o narrador está falando, e que o leitor lê, de fato, um trabalho de ficção, embora a tênue linha entre irreal e real se mescle nesta narrativa de Cortázar, propositalmente. O recurso também dá conta de, antecipadamente, acordar o leitor de seu "sonho ficcional".

Ao quebrar o contrato de ilusão desde o início, o autor dificulta a suspensão da descrença, ou seja, o envolvimento do leitor com a história como se ela fosse verdadeira, para facilitar a reflexão crítica e distanciada sobre as crenças e as ilusões cotidianas (BERNARDO, 2010, p. 166).

Com isso, estabelece-se um pacto diferente entre escritor e leitor, de mais cumplicidade e aproximação. Esta autoconsciência que se firma é potencializada, convidando o leitor a refletir sobre a escrita, juntamente com o autor. Assim, segundo Cortázar, a narrativa "não engana o leitor", 
mas dá-lhe algo como uma argila significativa, um começo de modelagem, com marcas de algo que talvez seja coletivo, humano e não individual, $\mathrm{Ou}$ melhor, dá-lhe uma espécie de fachada, com portas e janelas atrás das quais está se operando um mistério que o leitor cúmplice deverá procurar (e é disso mesmo que sai a cumplicidade) e que talvez jamais encontre (e disso é que vem o co-padecimento). O que o autor desse romance tiver conseguido para si mesmo se repetirá (agigantando-se, talvez, e isso seria maravilhoso) no leitor cúmplice (CORTÁZAR, 2005, p. 458).

Nesta nota atribuída a Morelli, parte do capítulo 79 de $O$ jogo da amarelinha, Cortázar deixa ainda mais clara a sua intenção de deslocar o leitor, alcançar este outro que lê, trazendo-o para dentro da trama. Além disso, também o provoca a acompanhar ativamente, de forma crítica, a construção da narrativa, e o processo de desmontagem do conto, que desnuda suas engrenagens de sustentação. Com esta atitude, o escritor acaba por chamar a atenção para a práxis executada por ele, desde a construção do personagem, como da voz do narrador:

me agradaria tanto poder escrever sobre Anabel como ele o teria feito se a tivesse conhecido e tivesse escrito um conto sobre ela. (...) Nesse caso Bioy teria falado de Anabel como eu serei incapaz de fazê-lo, mostrando-a próxima e profundamente e ao mesmo tempo guardando essa distância, esse desprendimento que decide pôr (não posso pensar que não seja uma decisão) entre alguns de seus personagens e o narrador. Para mim vai ser impossível, e não só porque tenha conhecido Anabel, visto que quando crio personagens também não consigo me distanciar deles (...) Não me será possível, pois sinto que Anabel vai me invadir já de início (CORTÁZAR, 1985, p. 146-147).
No excerto acima, que figura entre os primeiros parágrafos da narrativa, o autor estabelece o conflito característico do conto: a impossibilidade de dissociar autor, narrador e personagem. Como se, ao fim, todos estivessem interligados e surgissem dessa amálgama representada pelo ato criativo do escritor. Ao mesmo tempo, Cortázar assume o quanto a proximidade e o envolvimento direto, de uma narração em primeira pessoa, na voz de um narrador-escritor, parece impossibilitar a escrita de um conto ficcional tradicional que tenderia a distanciar-se da realidade, a fim de criar um universo próprio. O uso de um formato autobiográfico, como o diário (de registros da realidade), também apontaria para uma direção usualmente contrária à do ficcionista (de criar realidades inventadas), mas que, no conto analisado, acaba por fundir as duas possibilidades. Ao simular a escrita de um diário real, o autor transita claramente entre os limites do real $x$ ficcional, apoiando sua narrativa nesse difuso limiar.

Ao expor tal questão, o contista suscita o que Bernardo (2010) chama de metarrealidade, isto é, a capacidade de uma obra de provocar a sensação de real, causada pela revelação do processo, diluindo a fronteira entre ficção e realidade. Causando, portanto, a impressão de que o que é mostrado, ainda que dentro da obra ficcional, de fato aconteceu. Como simulacro do mundo real.

No conto analisado, podemos perceber que a escolha do tipo de narrador, do recurso metaficcional e da opção por simular um gênero textual que caracteriza escritas de registros de vivências e impressões do mundo real, causa um impacto no leitor, gerando uma dúvida sobre a veracidade e/ou ficcionalidade 
do narrado. Esta metarrealidade criada por Cortázar em seu conto pode ser vista como:

aquela realidade que a ficção constrói e que surge, para o leitor e para o espectador, como "mais real do que o real", ou seja, como mais intensa, vívida e viva do que a vida cinzenta que se tinha antes de a arte iluminá-la (...) encontra-se além da realidade (BERNARDO, 2010, p. 189).

Com isso, o conto provoca o leitor a ampliar sua percepção e permanecer atento ao que é narrado, a fim de acompanhar o esforço do narrador em contar a sua história, especialmente a forma como ele o faz, configurando o que Hamburger (2013) chama de "efeito estético", em uma perturbação voluntária da ilusão da ficção, utilizando uma voz que aumenta a insinuação de real, ao usar um discurso testemunhal. E, assim, mais uma vez o paradoxo está montado e questiona o leitor: o que é real ou fictício no que você lê?

Dessa forma, esta simulação de realidade, criada pelo uso do procedimento metaficcional, busca mostrar ao leitor o dilema ficcional e de que maneira o escritor luta com ele a fim de construir sua narrativa, fazendo com que o leitor reflita sobre o ofício da escrita de ficção e do quanto ela representa um espelhamento da condição real do autor.

Sabemos que metaficção é uma ficção que explicita sua condição de ficção, quebrando o contrato de ilusão entre o autor e o leitor (...) ao mesmo tempo revelam-se ficção que igualmente não escondem que são ficção, misturando as estações de maneira límpida e instigante. Assim que procuram retratar a realidade, mostram que o que chamamos de realidade não pode ser outra coisa senão o seu retrato ou seu espelho, como se demonstrassem que a realidade é sempre virtual, sempre simulacro (BERNARDO, 2010, p. 181).

A ideia de simulacro parece permear todo o conto, criando um efeito de perspectiva em abismo, ao narrar a tentativa de um autor de escrever um conto, aparentemente sem sucesso. Mesmo assim, ao acompanhar suas vicissitudes narrativas ao longo do percurso de criação, percebemos que mais do que isso está sendo contado. $\mathrm{E}$, ao fim, constatamos que, de uma forma ou de outra, o narrador alcançou seu objetivo e construiu uma narrativa sobre Anabel, ainda que entrecortada por suas considerações reflexivas sobre o processo de fazê-lo.

Cortázar apresenta-se, assim, não apenas como o autor por trás da obra, mas, com o uso do recurso autorreflexivo da metaficção, ao mesmo tempo, coloca-se como seu crítico, a analisar o processo da escrita e seu resultado, enquanto escreve. Dessa forma, ele mesmo coloca-se como leitor do que escreve, simultaneamente, dentro do conto.

Segundo Eagleton, "a crítica é uma forma de 'metalinguagem' - uma linguagem sobre outra linguagem - que se eleva acima de seu objeto" (2006, p. 206). Logo, está construída a boneca russa, a englobar uma linguagem dentro da outra.

Barthes fala da crítica como algo que 'cobre o texto tão completamente quanto possível com sua própria linguagem'; em Crítica e verdade (1966) o discurso crítico é considerado uma 'segunda linguagem' que 'flutua acima da linguagem primária da obra' (BARTHES apud EAGLETON, 2006, p. 206). 
A partir disso, o que Cortázar realiza em "Diário para um conto", pode ser interpretado como a tentativa de sobrepor linguagens, ao realizar uma narrativa contendo em si a sua própria crítica, criando, assim, dimensões de leitura, em que cada linguagem paira sobre a outra, formando um todo.

Podemos compreender que, com sua multiplicação de espelhos, a metaficção busca servir ao autor como forma de refletir sobre a sua verdade ficcional, por meio do questionamento dos limites e da ruptura de padrões, ao fazer uso de uma escolha por determinado "efeito estético". Desse modo, o escritor parece buscar por uma tentativa de dar vida à sua escrita, fazendo com que ela envolva o leitor por completo, como uma experiência real.

Com isso, Cortázar intenta transcender os limites do texto, dando-Ihe mais camadas e dimensões que a ficção por si só permite, ampliando-a. Ao trazer a figura do escritor para "fora", para além do seu papel concluso, para dentro da "cena", é como fazê-lo romper a barreira da solidão que cerca sua escrita. Solidão esta exposta no trecho final da narrativa:

Nenhum interesse, de verdade, porque procurar Anabel no fundo do tempo é sempre cair de novo em mim mesmo, e é tão triste escrever sobre mim mesmo ainda que queira continuar imaginando que escrevo sobre Anabel (CORTÁZAR, 1985, p. 182).

Mais do que espelho do autor, do que seu duplo, o recurso metaficcional serve para habitar sua solidão, compartilhando-a com o leitor, fazendo com que a escrita não seja um local de isolamento do escritor, mas sim onde ele dialoga, constrói sua narrativa frente ao seu ouvinte, o leitor, que também deixa de estar só frente às páginas do livro.

Este talvez seja o ponto fundamental para compreender a metaficção em Cortázar, que, ao propor um jogo com seu leitor, demonstra um generoso gesto de incluí-lo dentro da ficção, para ter com quem jogar. Para isso, ele revela a encenação por trás da mágica e, em troca, ganha a presença do outro em seu número.

\section{Os labirintos da criação da personagem}

A estranheza que logo capta a atenção do leitor, ao iniciar a leitura de "Diário para um conto", parece dilatar-se ao longo do texto. Tanto ao perceber que se está diante de um conto em processo quanto da criação de um personagem, e, igualmente, da escolha da abordagem que deverá ser feita para desenvolvê-la, conforme o narrador pondera.

A criação de personagens constitui-se em um importante pilar do processo de construção de uma narrativa. No texto de Cortázar, vemos o quanto ele evidencia tal fato, buscando demonstrar a complexidade da tarefa de tentar dar vida a um ser criado no papel para conseguir captar a essência do narrado. Embora baseado em memórias de uma suposta pessoa real, de seu passado, o narrador confronta a árdua empreitada de trazer sua representação para o universo ficcional.

Curioso, ontem não pude continuar escrevendo (...), precisamente talvez porque senti a tentação de fazê-lo e lá estava somente Anabel, sua maneira de me contar o fato. Como falar de Anabel sem imitá-la, isto é, sem falsificá-la? Sei que é inútil, que se entro nisso terei de me submeter à sua lei, e que me falta a habilidade e a noção de distância de Bioy para me manter longe e marcar 
pontos sem dar demasiado as caras. Por isso jogo estupidamente com a ideia de escrever tudo o que não é verdadeiramente o conto (de escrever tudo o que não seria Anabel, claro) (CORTÁZAR, 1985, p. 148).

Os conceitos de imitação e falsificação parecem assombrar o escritor ao tentar "criar" sua personagem. Para dar vida a esse ser, o narrador debate-se em sua escrita, refletindo sobre a anunciada impossibilidade de dar forma a ele, de maneira original, sem trair a essência de sua identidade. Com essa questão, Cortázar toca no complicado ato de criação do personagem, da luta com a linguagem para conseguir transportar este "recorde do mundo real" para o texto, para imbuí-lo de vida, sem fazê-lo parecer apenas a cópia de um indivíduo, ou mera caricatura.

O narrador vê-se assombrado pela presente ausência de Anabel, uma necessidade de voltar a senti-la que, justamente, vem à tona a partir de uma antiga fotografia encontrada ao acaso dentro de um livro:

Essa foto de Anabel, colocada simplesmente como marcador num romance de Onetti e que reapareceu por mera ação da gravidade em uma mudança de dois anos atrás, tirar uma braçada de livros velhos da estante e ver surgir a foto, custar a reconhecer Anabel (CORTÁZAR, 1985, p. 151).

A relação da imagem com o nascimento da personagem, como dispositivo da escrita e como elemento central de um conto a ser criado, demonstra o quanto a fotografia, neste sentido, também representa essa luta entre representação $\times$ realidade, uma vez que revela apenas um fragmento, um plano do que foi retratado, assim como a escritura, que tenta capturar em vão o todo que constitui uma pessoa. Nesta luta contra o fracasso de apreender a totalidade de Anabel, o personagem acaba por depararse justamente com o oposto do todo, o vazio. É o que se evidencia ao utilizar uma passagem de um texto de Derrida, e ao utilizá-la para compreender seu próprio fazer:

eu enfrento um nada, que é este conto não escrito, um vazio de conto, uma fraude de conto, e de um modo que me seria impossível compreender sinto que isso é Anabel, isto é, que há Anabel embora não haja conto. E o prazer reside nisso, ainda que não seja um prazer e se pareça com alguma coisa assim como uma sede de sal, como um desejo de renunciar a toda escrita enquanto escrevo (entre tantas outras coisas porque não sou Bioy e não conseguirei nunca falar de Anabel como penso que deveria fazê-lo). (CORTÁZAR, 1985, p. 149-150).

A criação de Anabel enquanto personagem surge da necessidade de recriála a partir de lembranças, como se sua existência na ficção fosse uma forma de trazê-la de volta do passado. Neste sentido, o autor depara-se com sua impossibilidade, percebendo que o personagem, assim como a narrativa, não tem o alcance de apreender tudo o que ele gostaria de colocar no papel, em palavras. Logo, relata como o desejo do conto manifesta-se, mas não se realiza, lançando-o em um pleno vazio.

Se o processo de criação e, consequentemente, de escritura, acaba por lançar o escritor em um espaço escuro em que ele tenta construir caminhos e encontrar portas de saída, por mais que o autor tente, a escrita representa uma vã tentativa, e tudo é inconstante, exceto uma coisa permanece permanente nesta 
luta contra o vazio, ele próprio. É o que o narrador exterioriza no registro do dia 13 de fevereiro:

Ontem me irritei comigo mesmo, é divertido pensar nisso agora. De qualquer maneira já o sabia desde o princípio, Anabel não me deixará escrever o conto porque em primeiro lugar não será um conto e depois porque Anabel fará (como fez então sem sabê-lo, pobrezinha) tudo o que puder para me deixar só diante de um espelho. Basta-me reler este diário para sentir que ela não é mais que uma catalisadora que tenta me arrastar para o fundo mesmo de cada página, que por isso não escrevo, ao centro do espelho onde teria querido vê-la e no entanto vejo um tradutor público nacional devidamente diplomado, com sua Susana previsível e até cacofônica, suasusana, por que não a terei chamado Amália ou Berta. Problemas de escrita, qualquer nome não se presta a... (você vai continuar?). (CORTÁZAR, 1985, p.160-161).

Percebemos então o quanto a tentativa de escrever sobre o outro, o personagem, acaba revelando-se sempre mero reflexo do próprio autor. $\mathrm{O}$ conto em processo acaba por manifestar-se como um exercício de escritura, com o intuito de recriar a vida, experiências passadas e pessoas de outrora, viajando no tempo, como uma maneira de ressignificá-las, e melhor compreendêlas, buscando sua essência, sua verdade. Verdade esta que, neste jogo de espelhos, acaba refletindo tão somente o rosto do escritor.

\section{Considerações finais}

A partir da análise realizada, podemos inferir o quanto a utilização da narrativa metaficcional expõe o processo de criação literária, em especial da criação de personagens, mostrando seus percalços e vicissitudes. A escolha de Cortázar demonstra uma forma de transformar o texto em palco, em matéria viva, trazendo o leitor para dentro da cena. Como acompanhante, testemunhando a construção não só da personagem, mas do conto, por meio da qual o leitor pode acessar limites e reflexões vivenciados pelo narrador-autor, "co-participando" de sua narrativa, como um dia idealizou o Cronópio.

Neste sentido, o texto evidencia o recurso metafictício e faz dele não apenas tema narrativo como também estrutura. Igualmente se percebe, no conto de Cortázar, que a metaficção transcende o aspecto temático e formal, tornando-se ponto central da narrativa. A metaficção, através da análise realizada, pode ser percebida como procedimento que visa iluminar o texto, bem como os bastidores da escritura.

Ao escrever um diário de um conto em processo, e questionar-se sobre o que é de fato um conto, o autor testa os limites do gênero, da forma narrativa, cruzando fronteiras não só entre gêneros textuais e literários, mas entre realidade e ficção. Pois, conforme Bernardo, "porque suspeita do real, a ficção produz sobre ele uma nova perspectiva e, consequentemente, uma segunda realidade" (2010, p. 259). Ao amplificar a ficção, o procedimento metaficcional a torna "mais real do que o real" (BERNARDO, 2010, p. 259).

Acima da realidadee da ficção, a narrativa assume uma carga etérea, onírica, como se fosse a própria ficção sonhando sobre si mesma. Flutuando acima da realidade, como diria Cortázar, a personagem Anabel surge como a senha para decodificar este 
universo em construção, esta estrutura criada especialmente para ela "acontecer". A escrita do conto, neste caso, passa a ser a ferramenta, a ponte para tentar alcançá-la, retirando-a do passado, dentre memórias vagas e difusas.

Mas às vezes não é assim porém algo muito mais sutil. Às vezes entra-se em um sistema de paralelas, de simetrias, e talvez por isso há momentos e frases e acontecimentos que se fixam para sempre em uma memória que não tem demasiados méritos (a minha em todo caso) já que esquece tanta coisa mais importante. Não, nem sempre há invenção ou cópia. Ontem à noite pensei que tinha de continuar escrevendo tudo isto sobre Anabel, que possivelmente me levaria ao conto como verdade última (CORTÁZAR, 1985, p. 166-167).

Ao usar a estrutura memorialística do diário como a tentativa impossibilitada de conto, o autor assume a incapacidade do escritor em reconstruir o real, falseando-o como o narrador fazia com as cartas, sentimentos e, talvez, até mesmo com seu diário. Como vimos inicialmente, é este o papel do poeta, ser um fingidor. Contudo, assim como o narrador não conseguiu controlar o desenrolar dos acontecimentos por meio de suas cartas, também não consegue manter o controle sobre o conto em desenvolvimento, que mais uma vez parece ter suas rédeas tomadas por Anabel.

Ainda que decepcionado diante da tentativa frustrada de escrever o conto, permeada por folhas soltas, conforme confessa o narrador, a narrativa estruturase, mostrando que para existir não depende dos formatos convencionais, de um narrador eficiente e de um personagem sólido.
A verdade é que teria gostado de escrever sobre tudo isto, fazer um conto sobre Anabel e aqueles tempos, possivelmente teria me ajudado a me sentir melhor depois de tê-lo escrito, deixar tudo em ordem, mas já não creio que vá fazê-lo, existe este caderno cheio de farrapos soltos, esta vontade de começar a completá-los, de encher os vazios e contar outras coisas de Anabel, mas a única coisa que consigo dizer a mim mesmo é que gostaria tanto de escrever esse conto sobre Anabel e finalmente é uma página a mais no caderno, um dia a mais sem começar o conto (CORTÁZAR, 1985, p. 181-182).

Este diálogo estabelecido, do narrador com ele mesmo, esta escrita sobre a escrita, ainda assim, revela-se uma forma de narrar. A presença da metaficção parece potencializar isto, como que dizendo que mesmo não parecendo um conto (aos moldes tradicionais) é um conto; mesmo mostrando suas engrenagens por detrás da cortina, não representa a realidade, é fingimento, ficção.

Cortázar, como bom criador de mundos, por meio de seu conto, apresenta um texto significativo para o entendimento do universo da criação literária e seus labirintos, com a criação de narradores, personagens, conflitos, conteúdos e formas narrativas que se desvelam ao escritor sempre que iniciada sua jornada criativa. Dessa forma, coloca o leitor dentro do universo ficcional de um escritor em crise, passivo da vontade dos personagens e do texto, como se estes fossem entidades vivas.

Com isso, o autor permite que se experencie o próprio fazer literário, uma prática feita de elementos lúdicos, mas também de solidão e confronto com os limites da linguagem, da forma textual, bem como também com seus próprios limites. Pois, assim como a vida, 
a literatura mostra-se complexa e contraditória.

Neste sentido, o texto de Cortázar, ao valer-se do recurso da metaficção provoca uma reflexão profunda tanto sobre o que é de fato um conto quanto sobre as motivações por trás do contar. As inquietações que levam um indivíduo a querer escrever, a buscar na ficção uma forma de recriar a vida, duplicando-a para vivê-la de diferentes formas. Como uma potência da realidade, em forma de palavras.

\section{Referências}

AVELAR, Mario. Metaficção. In: CEIA, Carlos (Org.). E-Dicionário de termos literários. Disponível em: <http://www.edtl.com.pt/businessdirectory/6157/metaficção.html>. Acesso em: 11 ago. 2015.

BERNARDO, Gustavo. O livro da metaficção. Rio de Janeiro: Tinta Negra Bazar Editorial, 2010.

CORTÁZAR, Julio. Fora de hora. Tradução Olga Savary. Rio de Janeiro: Nova Fronteira, 1985.
CORTÁZAR, Julio. Obra crítica. Tradução Paulina Wacht e Ari Roitman. Rio de Janeiro: Civilização Brasileira, 2001. Vol. 3.

CORTÁZAR, Julio. O jogo da amarelinha. Tradução Fernando de Castro Ferro. 9. ed. Rio de Janeiro: Civilização Brasileira, 2005.

CORTÁZAR, Julio. Valise de Cronópio. Tradução Davi Arrigucci Jr. e João Alexandre Barbosa. São Paulo: Perspectiva, 2008.

EAGLETON, Terry. Teoria da literatura: uma introdução. Tradução Waltensir Dutra. São Paulo: Martins Fontes, 2006.

GARDNER, John. A arte da ficção. Tradução Raul de Sá Barbosa. Rio de Janeiro: Civilização Brasileira, 1997.

HAMBURGER, Käte. A lógica da criação literária. Tradução Margot P. Malnic. São Paulo: Perspectiva, 2013.

LODGE, David. A arte da ficção. Tradução Guilherme da Silva Braga. Porto Alegre: L\&PM, 2010.

YURKIEVICH, Saúl. Um encontro do homem com seu reino. In: Obra crítica. Rio de Janeiro: Civilização Brasileira, 1998. Vol. 1.

Recebido: 14 de julho de 2017. Aceite: 4 de agosto de 2017. 